\title{
New and rare lichens and allied fungi from the Novgorod Region, Russia
}

\author{
Irina S. Stepanchikova ${ }^{1,2}$, Ludmila V. Gagarina ${ }^{1}$ \& Olga A. Kataeva ${ }^{1}$ \\ ${ }^{1}$ Laboratory of Lichenology and Bryology, Komarov Botanical Institute RAS, \\ Professor Popov St. 2, 197376 St. Petersburg, Russia. \\ E-mails: stepa_ir@mail.ru,kvercus@yandex.ru,kataevaoa@mail.ru \\ ${ }^{2}$ Department of Botany, St. Petersburg State University, Universitetskaya emb. 7/9, 199034 St. Petersburg, Russia.
}

\begin{abstract}
Novgorod Region, 34 of them are new to the region. Leptogium biatorinum is new to European Russia. Nephromopsis laureri is red-listed in Russian Federation and should be included in the Red Data Book of the Novgorod Region. Most noteworthy records are briefly discussed. Two species - Collema callopismum and Hertelidea botryosa - are excluded from the lichen list of the Novgorod Region.
\end{abstract}

\section{INTRODUCTION}

The present paper is the outcome of one-week field excursion in June 2012 made by the first and second authors, and of the revision of earlier collections by the third author. During the excursion we visited the northern part of the Novgorod Region, close to its border, and investigated the lichens of the most wooded and remote area in the region. The most important findings are presented in this paper.

The lichen diversity of the Novgorod Region has been studied since the end of the 19th century. The first lichen collection of about 50 specimens was made by the botanist V. L. Komarov in 1889-90 in Borovichi district (southeastern part of the region). Komarov's collection was determined by A. A. Elenkin, V. P. Savicz and himself, and stored in the lichen herbarium of St. Petersburg Botanical Garden (Komarov Botanical Institute RAS at present). In 1910 Savicz continued the lichenological studies in that district; his collection included ca. 170 samples. Some years later Savicz published an important paper "On the lichens of Novgorod Region" in which data on 140 species were presented (Savicz, 1914). According to the herbarium and literature data, 156 lichen species were known for the territory of the Novgorod Region before the comprehensive inventory of the lichen flora was initiated in 1995 by the third author. Recent data on the regional diversity were summarized in "Cadaster of flora of Novgorod Region"; the book contains data on 283 lichen species (Kataeva, 2009). After that, some additions were published (Kataeva, 2010, 2013; Gagarina \& Stepanchikova, 2013).
In the present paper 44 species are listed, 34 of them are new to the Novgorod Region. Today, lichen biota of the Novgorod Region is known to comprise 336 species.

\section{MATERIALS AND METHODS}

\section{Study area}

The Novgorod Region is a large $\left(54501 \mathrm{~km}^{2}\right)$ part of North-West of European Russia, located between Leningrad, Vologda, Pskov and Tver regions (Fig. 1). The western part of the Region is represented by flat lowland with Ilmen' Lake in its centre. Eastern part has more rugged relief, since the watershed of Baltic and Caspian seas (Valday Upland) is partly located there. Phytogeographically the Novgorod Region belongs to the hemiboreal zone - or, from alternative point of view, the northern part of the region is situated on the border of hemiboreal and southern boreal zones (Sennikov, 2005).

The territory of modern Novgorod Region has a very long history of human activity. It was generally more inhabited in the past and forests were more intensively cut than in the neighbouring regions. At present, only small patches of oldgrowth coniferous, deciduous (broad-leaved) and mixed forests have remained in its territory, and these are scarcer than, for example, in the eastern part of the Leningrad Region. Only some of these key forest areas are protected.

Over the last years, the forests of the Novgorod Region are encountering a new prob- 


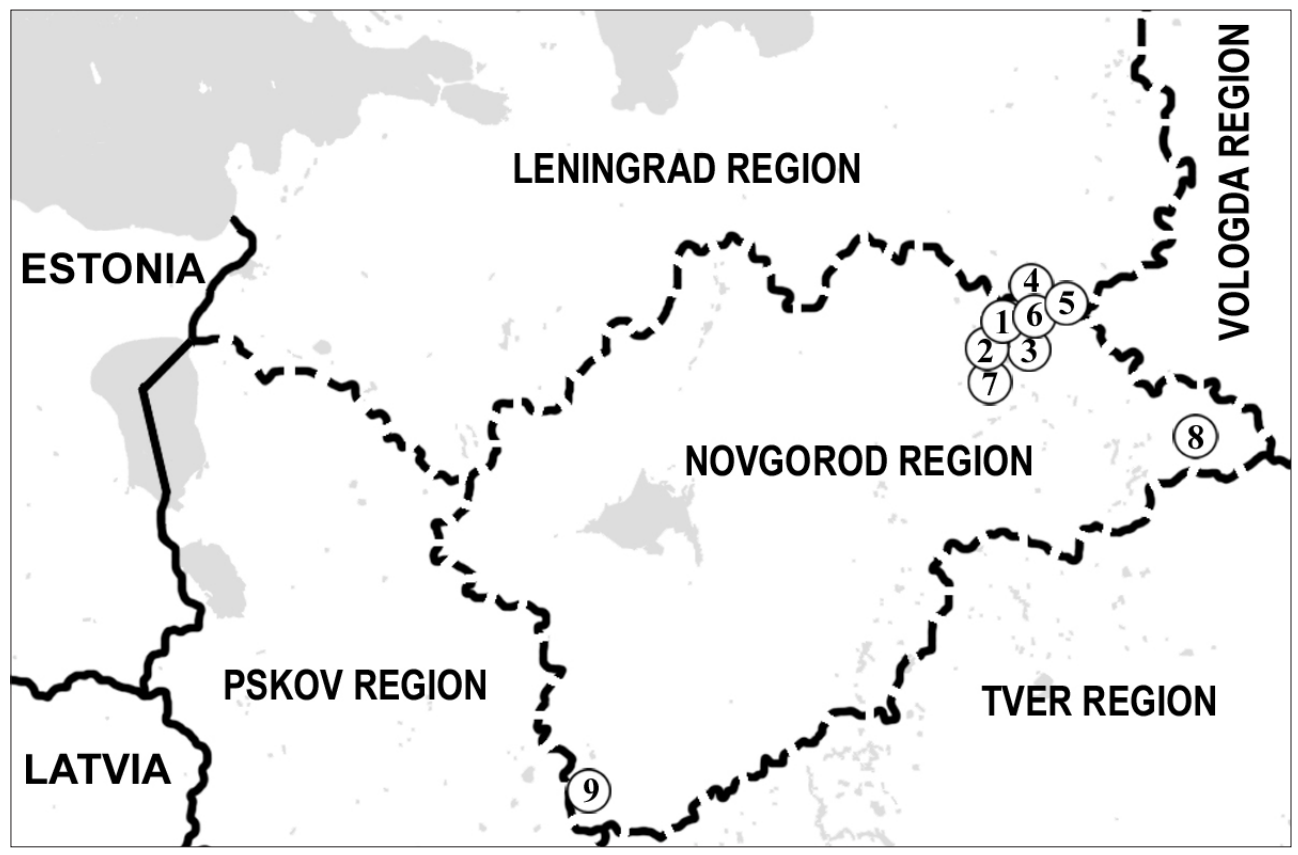

Fig. 1. Location of the Novgorod Region in the Russian North-West and collecting sites (numbers) in the study area.

lem: the regional net of protected natural areas was re-organized, and some valuable territories lost their statuses. Recently several protected areas were restored, but the problem of nature protection in the Novgorod Region remains dire. Therefore, any information on the regional biodiversity, especially on the distribution of rare and endangered species, is important.

\section{Collecting and identification}

The largest part of material was collected in June 2012, in Khvojninsky district of the Novgorod Region. Representative specimens are deposited in the herbarium of Komarov Botanical Institute RAS (LE). Lichen substances were analyzed by standard technique of high performance thinlayer chromatography (HPTLC) using solvent systems A, B and C (Orange et al., 2001). Illustration of Leptogium biatorinum was made with dissecting microscope Carl Zeiss STEMI-2000 CS with mounted camera AxioCam ICc 3. Brief discussions and distribution information for the most interesting records (new to European Russia or red-listed in Russian Federation) are included. The nomenclature of taxa follows Nordin et al. (2011).

\section{List of localities}

Khvojninsky district (coll. I. S. Stepanchikova \& L. V. Gagarina, 02-07.06.2012). [1] Ca. $7.5 \mathrm{~km}$ NEE of Antsiferovo, $4 \mathrm{~km} \mathrm{~N}$ of Rakitinskoe lake: 1.1 - old pine forest with Sphagnum spp. and Vaccinium vitis-idaea L. (58 58'43"N, 3409'2630"E); 1.2 - aspen-birch-spruce swampy forest with Sphagnum spp. and Vaccinium myrtillus L. (58 58 '30-36"N, 3409'26-38"E); 1.3 - margin of pine bog woodland with Eriophorum vaginatum L. (58 $\left.58^{\prime} 57^{\prime \prime N}, 34^{\circ} 09^{\prime} 48^{\prime \prime} \mathrm{E}\right) ; 1.4$ - spruce forest with Sphagnum spp. and Vaccinium myrtillus (58 $\left.58^{\prime} 58^{\prime \prime N}, 34^{\circ} 09^{\prime} 47^{\prime \prime E}\right)$. [2] Ca. $9 \mathrm{~km} \mathrm{SE}$ of Antciferovo, SW shore of Rakitinskoe Lake: 2.1 - young spruce forest with mosses, Vaccinium myrtillus and ferns $\left(58^{\circ} 54^{\prime} 42^{\prime \prime} \mathrm{N}, 34^{\circ} 07^{\prime} 35^{\prime \prime} \mathrm{E}\right)$; 2.2 - swampy black alder forest with birch and Carex spp. $\left(58^{\circ} 54^{\prime} 40^{\prime \prime} \mathrm{N}, 34^{\circ} 08^{\prime} \mathrm{O} 2^{\prime \prime} \mathrm{E}\right) ; 2.3$ - spruce forest with mosses and Vaccinium myrtillus (58 54'36-40'N, 3408'25-43"E). [3] Ca. 4 km NW of Pes': 3.1 - spruce forest with mosses (58 $\left.56^{\prime} 32^{\prime \prime} \mathrm{N}, 34^{\circ} 16^{\prime} 32^{\prime \prime} \mathrm{E}\right)$; 3.2 - spruce-birch forest with Sphagnum spp., Carex spp. and herbs (58 $\left.56^{\prime} 33^{\prime \prime} \mathrm{N}, 34^{\circ} 16^{\prime} 28^{\prime \prime} \mathrm{E}\right) ; 3.3$ - spruce forest with Sphagnum spp. and Vaccinium myrtillus 
(58 56'38'N, 34¹6'21'E). [4] Ca. $16 \mathrm{~km} \mathrm{NW}$ of Zhiloy Bor, S of Berezoradinskoe lake, $1.5 \mathrm{~km} \mathrm{~W}$ of Zaozer'ye village: 4.1 - aspen forest with Rubus saxatilis L. on slope $\left(59^{\circ} 09^{\prime} 17-18^{\prime \prime} \mathrm{N}, 34^{\circ} 20^{\prime} 56^{\prime \prime}-\right.$ $21^{\prime} 00$ "E); 4.2 - old aspens in mixed secondary forest $\left(59^{\circ} 09^{\prime} 26-27^{\prime \prime} \mathrm{N}, 34^{\circ} 20^{\prime} 06^{\prime \prime}-10^{\prime \prime} \mathrm{E}\right) ; 4.3$ - old aspen near the earth-road $\left(59^{\circ} 09^{\prime} 48^{\prime \prime} \mathrm{N}\right.$, $\left.34^{\circ} 19^{\prime} 43^{\prime \prime} \mathrm{E}\right) ; 4.4$ - secondary aspen forest with young spruces $\left(59^{\circ} 09^{\prime} 58^{\prime \prime} \mathrm{N}, 34^{\circ} 19^{\prime} 42^{\prime \prime} \mathrm{E}\right)$; 4.5 old aspens in younger spruce forest $\left(59^{\circ} 10^{\prime} 14\right.$ $16^{\prime \prime N}, 34^{\circ} 19^{\prime} 43-49^{\prime \prime E}$ ). [5] S of Zdymlya lake, 6-7 km NW of Zhiloy Bor: 5.1 - spruce forest with mosses and Vaccinium myrthillus $\left(5^{\circ} 07^{\prime} 10^{\prime \prime} \mathrm{N}\right.$, $\left.34^{\circ} 30^{\prime} 52^{\prime \prime E}\right) ; 5.2$ - pine bog woodland with dwarf shrubs $\left(59^{\circ} 07^{\prime} 32-42^{\prime \prime} \mathrm{N}, 34^{\circ} 30^{\prime} 16-47^{\prime \prime E}\right)$; 5.3 - old pine-birch bog woodland with Eriophorum vaginatum $\left(59^{\circ} 07^{\prime} 26^{\prime \prime} \mathrm{N}, 34^{\circ} 31^{\prime} 08^{\prime \prime} \mathrm{E}\right)$; 5.4 - aspen-spruce forest with mosses and Oxalis acetosella L. $\left(59^{\circ} 07^{\prime} 15^{\prime \prime} \mathrm{N}, 34^{\circ} 30^{\prime} 42^{\prime \prime} \mathrm{E}\right)$. [6] Ca. $21 \mathrm{~km}$ NWW of Zhiloy Bor, ca. $2 \mathrm{~km} \mathrm{~N}$ of Cheryomushki village and Nanderskoe lake: 6.1 - old-growth spruce-birch-pine forest with mosses and Vaccinium vitis-idaea $\left(59^{\circ} 06^{\prime} 26^{\prime \prime} \mathrm{N}\right.$, $\left.34^{\circ} 13^{\prime} 52^{\prime \prime} \mathrm{E}\right) ; 6.2$ - old-growth swampy pinespruce forest with Vaccinium myrtillus and

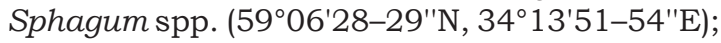
6.3 - pine bog woodland with Vaccinium myrtillus and Rubus chamaemorus L. (59 $06^{\prime} 32-34^{\prime \prime} \mathrm{N}$, $\left.34^{\circ} 14^{\prime} 05-08^{\prime \prime E}\right) ; 6.4$ - birch-spruce-pine forest with Sphagnum spp. and Vaccinium myrthillus (5906'38-44"N, 34²14'10-20"E); 6.5 - pine bog woodland with Vaccinium myrthillus $\left(59^{\circ} 07^{\prime} 00-\right.$ $07^{\prime} 01^{\prime \prime N}$; 34 $13^{\circ} 45-54^{\prime \prime E)}$; 6.6 - pine bog woodland $\left(59^{\circ} 06^{\prime} 59^{\prime \prime N}\right.$; 34 $\left.14^{\circ} 03^{\prime \prime} \mathrm{E}\right)$. [7] Karstovye Ozera protected area. Ca. $4 \mathrm{~km}$ SW of Safonovo village, $\mathrm{N}$ of Schuchje lake, $\mathrm{S}$ of Gorodno: 7.1 - pine bog woodland with Ledum palustre $\left(58^{\circ} 49^{\prime} 25^{\prime \prime} \mathrm{N}, 33^{\circ} 58^{\prime} 17^{\prime \prime} \mathrm{E}\right)$; 7.2 - herb-rich birchpine-spruce forest with springs $\left(58^{\circ} 49^{\prime} 20-22^{\prime \prime} \mathrm{N}\right.$, 335' 23-29"E); 7.3 - spruce forest with Sphagnum spp. and Vaccinium myrthillus (58 $49^{\prime} 19^{\prime \prime} \mathrm{N}$, $33^{\circ} 58^{\prime} 41^{\prime \prime E}$ ). Pestovo district (coll. O. A. Kataeva, 03.07.2004). [8] Okhona village: southern slope of sand pit $\left(58^{\circ} 34^{\prime} \mathrm{N}, 35^{\circ} 38^{\prime} \mathrm{E}\right)$. Kholm district (coll. O. A. Kataeva, 24.06.2009). [9] Near the road between Fryunino and Zamoshye villages: a meadow $\left(57^{\circ} 04^{\prime} \mathrm{N}, 30^{\circ} 45^{\prime} \mathrm{E}\right)$.

\section{THE SPECIES}

Abbreviations and symbols: \# - lichenicolous fungus; (\#) - facultatively lichenicolous fungus; + - non-lichenized saprobic fungus; * - new species for the Novgorod Region; IND/SPEC indicator species/habitat specialist of biologically valuable forests in the Southern Taiga of North-Western European Russia (Andersson et al., 2009); R - species red-listed in the Novgorod Region (List..., 2011).

Alectoria sarmentosa (Ach.) Ach. ssp. Sarmentosa - on bark of Picea sp., 1.2, 6.4, 6.5, 7.1, 7.2; on bark of Betula sp., 7.2. IND, R. - The last record of the species in the Novgorod Region was made 20 years ago in the surroundings of Valday administrative centre, and most probably that locality is now destroyed.

* Anisomeridium POlYPORI (Ellis et Everh.) M. E. Barr - on bark of Populus tremula L., 1.2.

* ARThonia didyma Körb. - on bark of Populus tremula, 4.5.

* Arthonia leucopellaea (Ach.) Almq. - on bark of Picea sp., 1.2, 1.4, 2.3, 3.3, 6.4. SPEC.

*+ ARthothelium SCANDinAVicum Th. Fr. - on bark of Picea sp., 1.2.

* Biatora efFlorescens (Hedl.) Räsänen - on bark of Alnus glutinosa_(L.) Gaertn., 2.2.

BRYORIA NADVORNIKIANA (Gyeln.) Brodo et D. Hawksw. - on bark of Picea sp. (branches), $6.2,6.3,6.4,6.5,7.2$; on bark of Betula sp., 1.3, 7.2. R.

* Calicium denigratum (Vain.) Tibell - on standing deadwood of Pinus sylvestris L., 5.2, 6.3. IND.

* Chaenotheca BRAchypoda (Ach.) Tibell - on dead bark of Betula sp., 1.2, 4.5, 6.1. IND.

Chaenotheca stemonea (Ach.) Müll. Arg. - on lignum of Pinus sylvestris, 6.1. IND, R.

* Chaenotheca subroscida (Eitner) Zahlbr. - on bark of Picea sp., 1.2, 6.4; on standing deadwood of Pinus sylvestris, 6.1. SPEC.

*\# Chaenothecopsis consociata (Nádv.) A. F. W. Schmidt - on thalli of Chaenotheca chrysocephala (Turner ex Ach.) Th. Fr. growing on bark of Picea sp., 1.2, 1.4, 3.1, 3.3, 6.1, 6.4. IND.

*\#) Chaenothecopsis pusilla (Ach.) A. F. W. Schmidt - on lignum, 2.3, 6.1; on thallus of Chaenotheca stemonea growing on bark of Picea sp., 6.1.

*+ Chaenothecopsis savonica (Räsänen) Tibell on bark of Picea sp., 6.4.

* Cliostomum leprosum (Räsänen) Holien et Tønsberg - on bark of Picea sp., 1.2, 1.4, 2.3, 3.1, 6.2, 6.4; on bark of Pinus sylvestris, 7.1. SPEC. 
*\# Clypeococcum hypocenomycis D. Hawskw. on thallus of Hypocenomyce scalaris (Ach.) M. Choisy growing on pine deadwood, 5.2.

* Collema furfuraceum (Arnold) Du Rietz - on bark of Populus tremula, 2.3, 4.1.

* Collema nigrescens (Huds.) DC. - on bark of Populus tremula, 4.1, 4.2, 4.3, 4.5. SPEC.

EOPYRENUla LEUCOPLACA (Wallr.) R. C. Harris - on bark of Populus tremula, 4.5. - The species was found in Novgorod Region for the first time since 1940 (Kataeva, 2002).

Evernia DIVARICATA (L.) Ach. - on bark of Picea sp., 6.5, 6.6, 7.2; on bark of Betula sp., 7.2. SPEC, R. - The last record of the species in the Novgorod Region was made 20 years ago in the surroundings of Valday administrative centre, and most probably that locality is now destroyed.

Gyalecta TRUnCigena (Ach.) Hepp - on bark of Populus tremula, 1.2, 4.1, 4.2, 4.5; on bark of Sorbus aucuparia L., 4.2. SPEC, R.

* Hypocenomyce caradocensis (Leight. ex Nyl.) P. James et Gotth. Schneid. - on standing deadwood of Pinus sylvestris, 5.2.

* Hypocenomyce castaneocinerea (Räsänen) Timdal - on burnt standing deadwood of Pinus sylvestris, 1.3, 5.2, 5.3. IND.

* Hypocenomyce fRiesi (Ach.) P. James et Gotth. Schneid. - on bark of Picea sp., 3.3, 6.1; on standing deadwood of Pinus sylvestris, 5.3.

Hypogymnia VitTATA (Ach.) Parrique - on bark of Betula sp., 1.2, 3.3, 6.4; on bark of Populus tremula, 1.1, 1.2; on lignum of Pinus sylvestris, 6.4. SPEC, R.

* LeCANORA NoRVEgica Tønsberg - on bark of Pinus sylvestris, 7.1. - The specimen contains atranorin, protocetraric acid and fatty acid.

* Lecidea leprarioides Tønsberg - on bark of Picea sp., 6.4.

* Lecidea nYlanderi (Anzi) Th. Fr. - on bark of Pinus sylvestris, 7.1 ; on standing deadwood of Pinus sylvestris, 5.2.

* Leptogium biatorinum (Nyl.) Leight. - on sandy soil with lime carbonate admixture, 8; on sandy soil between mosses, 9. - New to European Russia. Distribution in Fennoscandia and Baltic countries: Sweden, Finland (Nordin et al., 2011), Latvia (Motiejūnaite et al., 2006), Lithuania (Motiejūnaitè, 1999). The species is characterized by (granulose-) squamulose-crustose thallus (Fig. 2), submuriform colourless spores and by inhab-

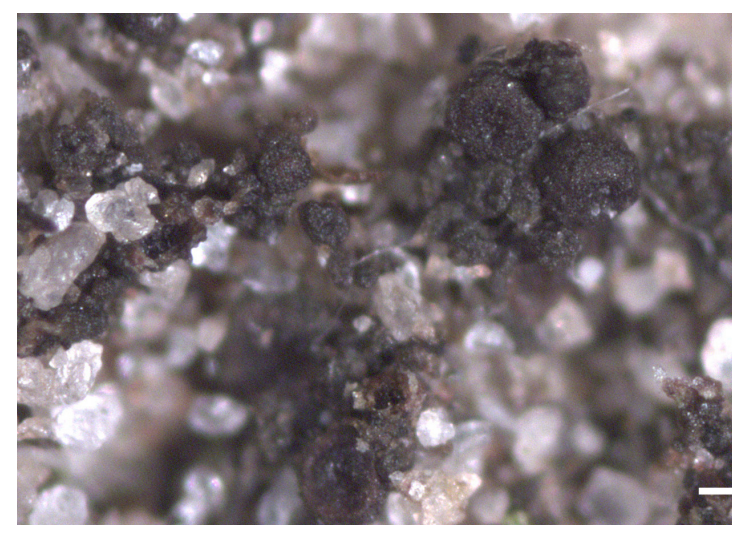

Fig. 2. Leptogium biatorinum, thallus with apothecia. Bar $0.5 \mathrm{~mm}$.

iting calcareous soil or rocks (Jørgensen, 2007).

* Leptogium teretiusculum (Wallr.) Arnold - on bark of Populus tremula, 1.1, 1.2. IND.

* Lichenomphalia umbellifera (L.: Fr.) Redhead et al. - on lignum (fallen rotten deadwood), $3.1,5.4$.

LOBARIA PUlmonaria (L.) Hoffm. - on bark of Populus tremula, 1.1, 1.2, 4.1, 4.2, 4.4, 4.5, 5.1; on bark of Sorbus aucuparia, 1.2 (not collected). SPEC, R. - The species is red-listed in Russian Federation (Red..., 2008). L. pulmonaria has a wide distribution throughout the whole country, but in most regions it inhabits relatively old and undisturbed natural forests. The typical communities for this species in the NorthWest of European Russia are old-growth mixed forests with aspen, spruce and birch with high humidity (Andersson et al., 2009). In Novgorod Region it occurs on trunks of aspen, spruce, oak, elm, birch and rowan, and usually is presented by numerous thalli from tiny to large ones (15-20 cm diam.). So far the species has been reported from eight localities in the Region, and most of the records are rather old.

*+ Microcalicium aHLneri Tibell - on standing deadwood of Pinus sylvestris, 5.2, 6.1, 6.4, 7.2. SPEC.

*\#) Microcalicium disseminatum (Ach.) Vain. on bark of Picea sp., 1.2, 1.4, 3.1, 6.4; on standing deadwood of Pinus sylvestris, 5.2, 6.1, 6.2. IND. 
* Mycoblastus sanguinarius (L.) Norman - on lignum of Pinus sylvestris (stump), 5.2.

Nephroma Bellum (Spreng.) Tuck. - on bark of Populus tremula, 1.2, 4.5. SPEC, R. - The species was found in the Novgorod Region for the first time since 1936 when it was collected in Valday area by Savicz, but that locality was destroyed (Kataeva, 2010).

* Nephroma Parile (Ach.) Ach. - on bark of Populus tremula, 1.1, 1.2, 4.5. SPEC.

NEPHROMA REsupinAtum (L.) Ach. - on bark of Populus tremula, 1.2, 4.5. SPEC, R. - The species was found in Novgorod Region for the first time since 1940 (Kataeva, 2002).

* Nephromopsis laUReri (Kremp.) Kurok. - on decorticated branch of old Picea sp., 6.4 (59 $06^{\prime} 43^{\prime \prime} \mathrm{N}, 3^{\circ} 14^{\prime} 20^{\prime \prime} \mathrm{E}$; not collected; Fig. 3-4). SPEC. - The species is red-listed in Russian Federation (Red..., 2008) and therefore is to be included in the Red Data Book of the Novgorod Region. In the Northern Europe, it is known from Russian localities only: Komi Republic (Pystina, 2003), Republic of Karelia (Fadeeva et al., 2007) and Leningrad Region (Stepanchikova et al., 2009). The species is much more common in the Urals, Southern Siberia and southern part of Russian Far East, as well as in the central and southern Europe, southern Asia, South America (Randlane, 1994; Red..., 2008). It occurs in coniferous and mixed forests in the mountains and on the plane. In Russia, $N$. laureri is generally confined to old-growth

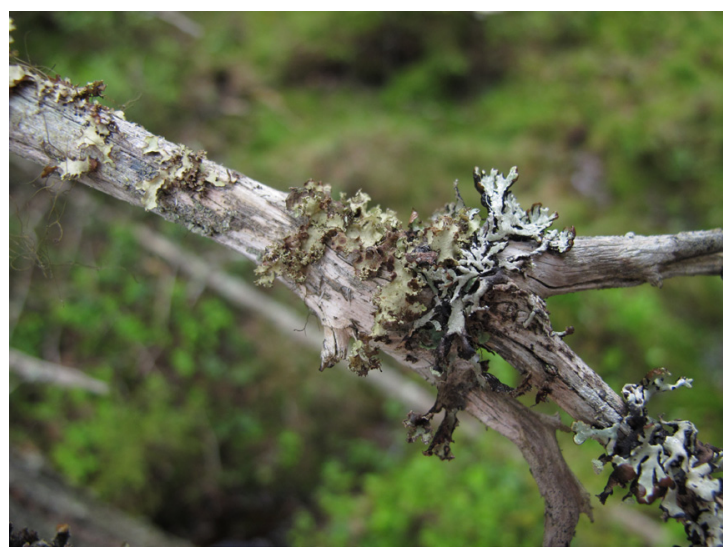

Fig. 3. Nephromopsis laureri on branch of old spruce. undisturbed forests; therefore it is included in the Federal Red Data book.

* Ochrolechia Androgyna (Hoffm.) Arnold s. str. - on bark of Betula sp., 3.3. - The specimen contains gyrophoric acid, lecanoric acid and three fatty acids called " $O$. androgyna B-unknowns" (see Kukwa, 2011).

*+ Phaeocalicium Praecedens (Nyl.) A. F. W. Schmidt - on bark of Populus tremula (twig), 1.2.

*+ SAREa difformis (Fr.) Fr. - on resin of Picea sp., 6.2.

*+ Stenocybe Pullatula (Ach.) Stein - on bark of Alnus glutinosa, 2.2.

* Tuckermannopsis Ciliaris (Ach.) Gyeln. - on bark of Betula sp. (branches), 2.1, 3.2.

\section{Taxa excluded from the lichen list of Novgorod Region}

Collema callopismum A. Massal. - reported by Kataeva (2009); the specimen was re-identified by O. Kataeva as Leptogium biatorinum. Hertelidea botryosa (Fr.) Printzen \& Kantvilas - reported by Savicz (1914, as Biatora botryosa Fr.) and cited by Kataeva (2002; 2009); the specimens were re-identified by C. Printzen as Trapeliopsis granulosa (Hoffm.) Lumbsch.

\section{DISCUSSION}

Most of the species presented above are typical for European boreal forests and (except

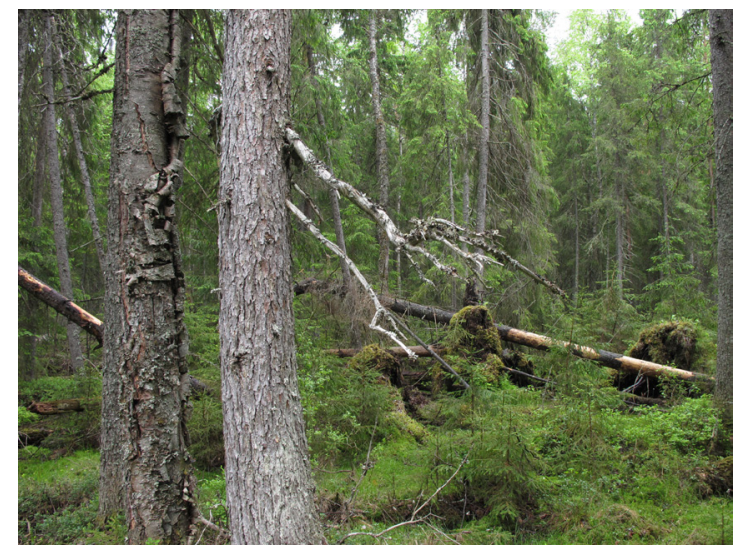

Fig. 4. Habitat of Nephromopsis laureri in birchspruce-pine forest in Novgorod Region, Khvojninsky district, ca. $21 \mathrm{~km}$ NWW of Zhiloy Bor. 
for Leptogium biatorinum) are known from the neighbouring Leningrad Region. The majority of newly recorded and rare species were collected in the old-growth coniferous forests. Twenty one species are indicators and habitat specialists of biologically valuable forests in the Southern Taiga of North-Western European Russia (Andersson et al., 2009). Nine species are red-listed and protected in the Novgorod Region (List..., 2011); two species - Nephromopsis laureri and Lobaria pulmonaria - are red-listed in the Russian Federation (Red..., 2008).

The majority of the investigated localities are biologically valuable (Andersson et al., 2009) oldgrowth relatively undisturbed forests which are rare in the region and should be under protection. Especially noteworthy is the spruce forest on the northern border of the Region (locality 6) where Nephromopsis laureri, Evernia divaricata, Alectoria sarmentosa and ten more indicator and specialist lichen species were found.

The studied localities in the northern part of the Novgorod Region are in the managed forest areas. Many of valuable forest patches are surrounded by secondary stands, only a few of them represent more continuous old forest communities. The most effective way to protect such fragmented forest patches is the forest certification, as well as the development of a network of regional protected areas. Further inventory work is important for revealing and protection of the regional biodiversity.

\section{ACKNOWLEDGEMENTS}

We wish to thank Jurga Motiejūnaitè (Vilnius) who reviewed our manuscript and Tiina Randlane (Tartu) for valuable corrections and suggestions, which have improved the quality of our work. We also would like to thank Olga Gurova (St. Petersburg) for linguistic help, and all our colleagues who participated in the field trips. The authors are grateful to the staff of CJSC "Nord" for organizing the field work in frame of FSC forest certification. The study was supported by Russian Foundation for Basic Research (grant 11-04-00901).

\section{REFERENCES}

Andersson, L., Alexeeva, N. \& Kuznetsova, E. (eds). 2009. Survey of biologically valuable forests in North-Western European Russia.Vol. 2. Identification manual of species to be used during survey at stand level. St. Petersburg. 258 pp. (In Russian).

Fadeeva, M. A., Golubkova, N. S., Vitikainen, O. \& Ahti T. 2007. Conspectus of lichens and lichenicolous fungi of the Republic of Karelia. Petrozavodsk. 194 pp. (In Russian).

Gagarina, L. V. \& Stepanchikova, I. S. 2013. Ramonia himelbrantii, a new corticolous lichen species from Russia. Graphis Scripta 25: 12-15.

Jørgensen, P. M. 2007. Collemataceae. - In: Nordic Lichen Flora. Volume 3. Cyanolichens. Nordic Lichen Society, Uddevalla, pp. 14-42.

Kataeva (Katenina), O. A. 2002. Lichen species of Novgorod Region. Novitates systematicae plantarum non vascularum 36: 114-143. (In Russian, English summary).

Kataeva, O. A. 2009. Lichens and lichenicolous fungi. In: Yurova, E. A., Krupkina, L. I. \& Konechnaya, G. Yu. (eds). Cadaster of flora of Novgorod Region. Veliky Novgorod, pp. 247-254. (In Russian).

Kataeva, O. A. 2010. Some results and perspectives of lichen studies in "Valdaysky" national park. In: Proceedings of "Valdaysky" national park: jubilee volume dedicated to the 20-th anniversary of "Valdaysky" national park foundation. Vol. 1. St. Petersburg, pp. 298-303. (In Russian).

Kataeva, O. A. 2013. To the lichen studies in Rdejsky reserve. In: Proceedings of Rdejsky state natural reserve. Issue 2. Veliky Novgorod, pp. 4-17. (In Russian).

Kukwa, M. 2011. The lichen genus Ochrolechia in Europe. Fundacja Rozwoju Uniwersytetu Gdańskiego, Gdańsk. 309 pp.

List of rare and endangered species (subspecies, populations) of animals, plants and fungi, naturally inhabiting Novgorod Region and included in the Red Data Book of Novgorod Region. 2011. Decree of Administration of Novgorod Region No 311, 12.07.2011.

Motiejūnaitè, J. 1999. Checklist of lichens and allied fungi of Lithuania. Botanica Lithuanica 5(3): 251-269.

Motiejūnaite, J., Suija, A., Lõhmus, P., Kuznetsova, E., Tõrra, T., Prigodina-Lukošienè \& I., Piterāns, A. 2006. New or noteworthy lichens, lichenicolous and allied fungi found during the 16th Symposium of Mycologists and Lichenologists in Latvia. Botanica Lithuanica 12(2): 113-119.

Nordin, A., Moberg, R., Tønsberg, T., Vitikainen, O., Dalsätt, Å., Myrdal, M., Snitting, D. \& Ekman, S. 2011. Santesson's Checklist of Fennoscandian 
Lichen-forming and Lichenicolous Fungi. Version April 29, 2011 - http://130.238.83.220/santesson/home.php (30 March 2013).

Orange, A., James, P. W. \& White, F. J. 2001. Microchemical methods for the identification of lichens. British Lichen Society, London. $101 \mathrm{pp}$.

Pystina, T. N. 2003. Lichens of taiga forests of European North-East (southern and middle taiga subzones). Ekaterinburg. 240 pp. (In Russian).

Randlane, T., Saag, A., Thell, A. \& Kärnefelt, I. 1994. The lichen genus Tuckneraria Randlane \& Thell - a new segregate in the Parmeliaceae. Acta Botanica Fennica 150: 143-151.

Red Data Book of Russian Federation (Plants and Fungi). 2008. Moscow. 855 pp. (In Russian).
Savicz, V. P. 1914. On the lichens of Novgorod Region. Izvestija Imperatorskogo Botanicheskogo Sada Petra Velikogo. Vol. 14. Suppl. I. Petrograd. 106 pp. (In Russian).

Sennikov A. N. 2005. Phytogeography of Northwest Russia (Saint-Petersburg, Pskov and Novgorod regions). Biogeography of Karelia. In: Proceedings of Karelian Research Centre RAS. Issue 7. Petrozavodsk, pp. 206-243. (In Russian).

Stepanchikova, I. S., Kuznetsova, E. S. \& Himelbrant, D. E. 2009. New records of lichens and allied fungi from the Eastern Leningrad Region. Folia Cryptogamica Estonica 46: 75-78. 
56 Folia Cryptog. Estonica 